\title{
Relationships Between Source Capacity, Value to Use, Value for Money and Loyalty of Visitors for Tourism Destination in Vietnam
}

\author{
Nhan Trong Phan ${ }^{1}$, Vi Truc Ho ${ }^{1} \&$ Phuong Viet Le-Hoang ${ }^{2}$ \\ ${ }^{1}$ Industrial University of Ho Chi Minh City, Vietnam \\ ${ }^{2}$ Graduate School, Ho Chi Minh City Open University, Vietnam \\ Correspondence: Nhan Trong Phan, Industrial University of Ho Chi Minh City, Vietnam.
}

Received: June 29, 2020

doi:10.5430/rwe.v11n5p380
Accepted: August 26, 2020

Online Published: September 13, 2020

URL: https://doi.org/10.5430/rwe.v11n5p380

\begin{abstract}
The purpose of this study is to identify and adjust the competitiveness scale to suit Vietnam's tourism. Accordingly, with inheriting The Competitive Advantage Model of Porter (1990), the authors focus on determining relationships among source capacity, value to use, value for money, and loyalty of visitors for tourism destination. With inheritance resources, created resources, and support resources are elements of source capacity, thereby creating a competitive advantage under two angles: value to use and value for money. It is this competitive advantage that attracts and retains tourists, creating customer loyalty for Vietnam destinations. By the method of expert interviews, the author has adjusted the factors and observed the variables to suit the case study in the tourism industry with the research area in Vietnam. In particular, the results show that the observed variables for source capacity are inherited entirely as well as the loyalty scale. Meanwhile, the scale of value to use and value for money is supplemented with two items according to expert opinion, including many unique experiences, suitable for financial condition.
\end{abstract}

Keywords: loyalty, source capacity, tourism, value to use, value for money

\section{Introduction}

Competitiveness refers to the success of a nation's economic growth, management strategies, politics, and institutions (Dwyer \& Kim, 2003); the ability to innovate to gain or maintain an advantageous position compared to other countries (Porter, 1990). Competitiveness has been experimented in many fields: economy, politics... In a smaller and more specific scope of tourism, competitiveness is also put much attention from theory to practice.

Many researchers have identified that the benefits of tourism come from the difference in competitiveness. In particular, the factors that make up the competitiveness of the destination include infrastructure and support services (Gearing, Swart \& Var, 1974; Caber et al., 2012); destination resources (Claver, López, Molina \& Tarí, 2007; Dwyer \& Kim, 2003; Go \& Govers, 2010; Ritchie \& Crouch, 2003). Assessing destinations' competitiveness in an increasingly competitive environment is an essential tool in positioning and marketing (Faulkner, Opperman, \& Fredline, 1999). A systematic assessment of the competitiveness of a destination can provide a more objective identifying the strengths and weaknesses, better assessing the competitive advantage of a travel destination, and contribute to development policies more effectively (Pearce, 1997).

In practical terms, according to the Vietnam National Administration of Tourism (2017), international visitors reached nearly 13 million, growing more than $25 \%$. The Government has also issued policies to facilitate tourism development, such as issuing visas for international visitors or issuing e-visas. Besides, direct flights to Vietnamese receive much attention; international airports have also been improved. Tourism in Vietnam is in the form of potential; the advantages of tourism are being exploited. However, Vietnam's tourism is still lagging behind the competing destinations in Asia and the world in general.

Destination competitiveness factors can not be applied to all cases and the main factors contributing to the competitiveness of economies and the level of development of each location is different (Porter, Sachs \& McArthur, 2001), it is essential to explore the factors about tourism destinations, especially the case of Vietnam. According to Ritchie \& Crouch (2003), every destination must verify the factors affecting its competitiveness to gain a more sustainable competitive advantage.

Therefore, the research identifies the key factors affecting Vietnam's tourism competitiveness through discovered relationships among source capability, competitive advantage, and loyalty of visitors for Vietnam's tourism 
destination. The research results aim to develop scales consistent with the characteristics of tourism in Vietnam based on the theory of competitive advantage to gives managers to have appropriate plans for sustainable tourism development in Vietnam.

\section{Literature Review}

\subsection{Tourism Destinations}

According to the Vietnam Tourism Law (2005), tourism destinations are places where tourism resources are invested and exploited in tourists' service. Besides, Cooper, Fletcher, Gilbert \& Wanhill (1998) define destinations as a combination of facilities and services built to meet the needs of travelers. As a whole, destinations attract tourists to take temporary breaks and range from a continent, a country, a state, a province, a city, or a village, a resort to a deserted island (Turnbull \& Uysal, 1995).

\subsection{The Competitive Advantage Model (Porter, 1990)}

The theory of competitiveness highlights two views: macro and micro. Although the two approaches are complementary and interdependent, their analytical framework and measurement criteria are different.

In terms of macro analysis, Source Capacity refers to the success of a nation's economic growth, management strategies, politics, and institutions (Dwyer \& Kim, 2003); ability to innovate to gain or maintain a favorable position relative to other countries in key industries (Porter, 1990).

In terms of microanalysis, Source Capacity is the ability to build, maintain, use and create new things, the competitive advantages of enterprises to create productivity and quality that are superior to competitors to keep growing and increase sales (Porter, 1990). Accordingly, to create a competitive advantage, companies often rely on the business's resources and capabilities. There are two basic types of competitive advantage:

- Cost advantage: exists when businesses can bring the same benefits to their competitors but at a lower cost.

- Difference advantage: this is assessed based on the benefits that the business must outstrip competitors, and the products must be competitive.

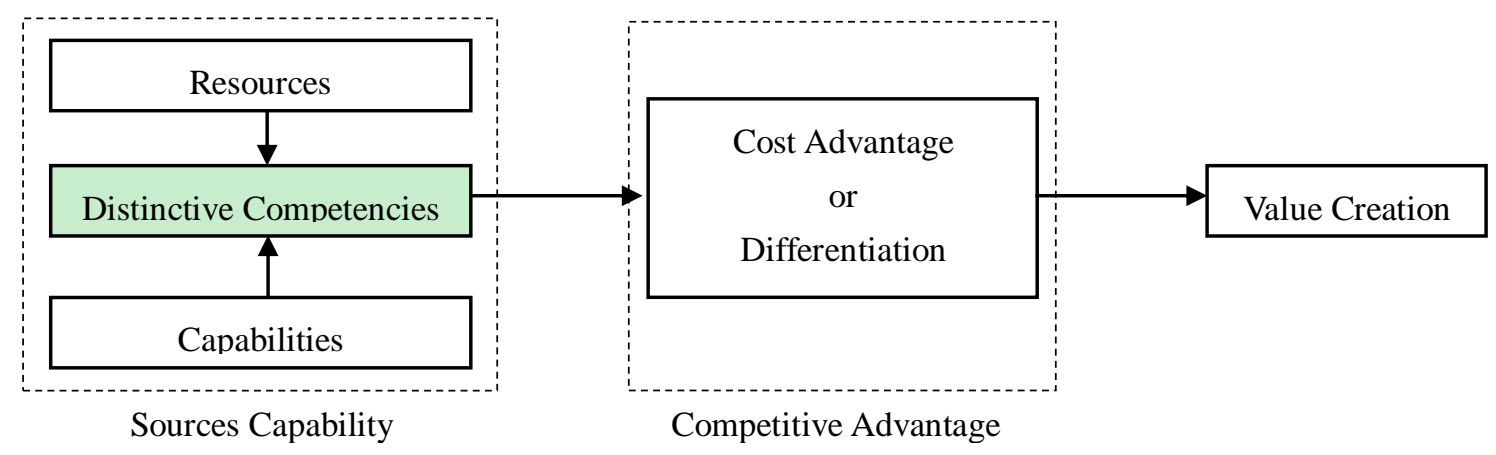

Figure 1. Model of sustainable competitive advantage

Source: Porter (1990)

According to Porter (1990), the main objective of an organization in creating a competitive advantage is based on its resources and capabilities, namely Source Capacity. Its key is to rely on its customers and improve its operational processes from the customer's point of view.

\subsection{Source Capacity of Destination}

Sources Capability of Destination are all assets owned by a destination (Vengesayi, 2013). It is the strategic asset that the destination can achieve to attract investment from businesses and attract tourists as well (Melian-Gonzalez \& Garcia-Falcon, 2003). Many researchers have identified that the benefits of tourism come from the difference in competitiveness of the destination. According to Enright \& Newton (2004), a competitive destination when it can attract and satisfy potential tourists. Also, destinations must ensure that the overall attractiveness and integrity of the destination's experience is equal to or surpasses the number of alternative destinations open to potential travelers (Ritchie \& Crouch, 2000). Through the theory of national competitiveness of Porter (2003), Ritchie \& Crouch (2000) identified factors that affect the competitiveness of destinations, including macro factors (industrial economy, 
terrorism, disease, ...) and the microenvironment (resources, infrastructure ...). Zainuddin, Radzi, Zahari \& Ong (2020), in the study of destination competitiveness and visitor behavior, experiments on the island of Langkawi in Malaysia, the authors have discovered that there are three factors of source competitiveness include Inheritance resources, Resources created, Supported resources. This view is also supported by several other authors (Azzopardi, 2011; Dwyer \& Kim, 2003; Mulec \& Wise, 2013). In particular, resource capacity can consider aspects of inherited resources, created resources, and support resources; management capacity related to organization, marketing, policy, planning/development, personnel management, and environmental management (Mulec \& Wise, 2013; Radzi \& Zahari, 2013). In conclusion, the correct calculation of each factor's value and the interaction between the factors helps determine which destination owns a sharp point, which locality or country should rely on for long-term tourism development and bring maximum efficiency.

\subsection{Destination Loyalty}

Destination loyalty is a prerequisite for forming an intention to return and introduce destinations to others (Kozak \& Rimmington, 2000). Crompton (1979) distinguished the first-time visitor's destination image, return visitors, and potential travelers as crucial. Because returning visitors not only provide a constant source of revenue for travel destinations, increase market share, create positive word of mouth, and also minimize marketing costs and activities. According to Crompton (1979), destination managers need to pay attention to the intention of returning travelers, indicating the difference between the motives of first-time visitors and returning tourists.

\section{The Proposed Research Model}

\subsection{The Proposed Research Model}

This research applies the theory of sustainable competitive advantage of Porter's (1990) whereby competitive capabilities affect competitive advantage and thereby create sustainable competitive value. To be more specific, in this article, the competitor inherits from the perspective of resource capacity, including inheritance resources, created resources, and support resources (Mulec \& Wise, 2013; Zainuddin, Radzi \& Zahari, 2013). Besides, the sustainable competitive advantage that makes the highest difference for businesses is to exploit organizational capacity in a valuable way to customers. The concept of co-creation of value in the context of a travel destination is considered to determine the interactions that affect customers' experiences, feelings, and assessments (Grönroos, 2006; Baron \& Harris, 2010). More specifically, the co-creation value consists of value-to-use, and value-for-money will create distinct advantages that enable businesses to compete with competitors (Vargo \& Lusch, 2004; Gronroos, 2009). Besides, according to Pike et al. (2010); Chen \& Myagmarsuren (2010); Bianchi, Pike \& Ling (2014), loyalty as a destination of creating real value for the business that comes from the attitude of customers. Considering the tourism environment and the competitiveness of the destination, as well as considering the aspect of customer loyalty, is to consider the value that businesses create to achieve sustainable competitive advantage in the market. From these views, the model proposed by the authors is as follow:

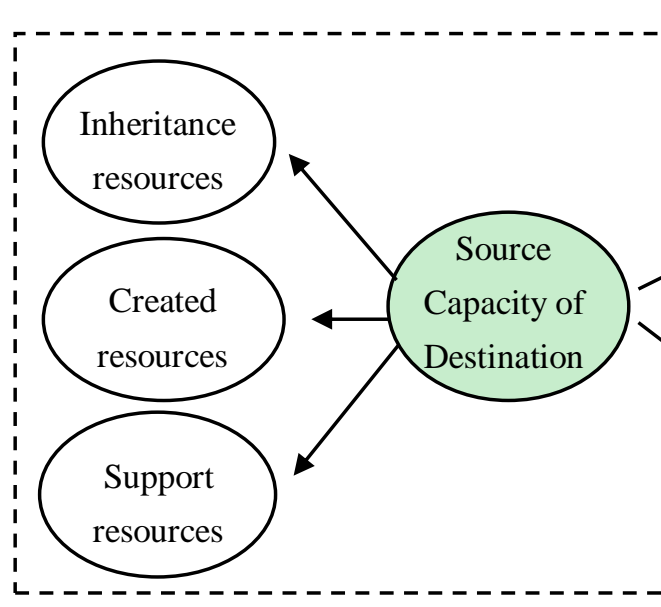

Source Capacity

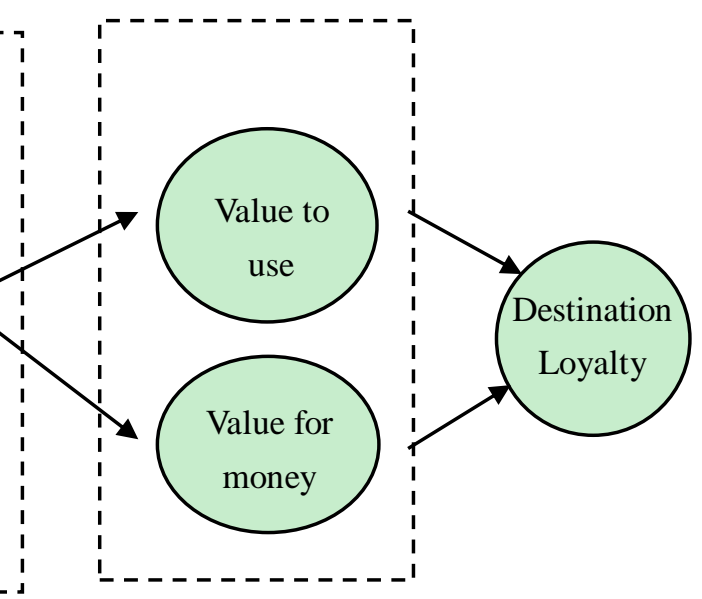

Competitive Advantage
Value Creation

Figure 2. The proposed research model 


\subsection{Relationships Among Source Capacity, Value to Use, Value for Money and Loyalty of Visitors for Tourism Destination}

\subsubsection{Relationships Among Source Capacity, Value to Use and Value for Money}

The resource capacity of a tourist destination is the core tourism attribute necessary for the formation and development of a destination. In particular, resource capacity is considered under three perspectives: inherited resources, created resources, and support resources (Zainuddin, Radzi, Zahari \& Ong, 2020). Inheritance resources represent potential resources for tourism development, including natural and cultural resources, and the way destinations are embraced for tourism development (Dwyer \& Kim, 2003; Mulec \& Wise, 2013; Zainuddin, Radzi, Zahari \& Ong, 2020). The resources created are divided into five categories: tourism infrastructure, activity area, shopping, entertainment / special events, and festivals. Also agree when experimenting with their case study (Dwyer \& Kim, 2003; Mulec \& Wise, 2013). The elements of supported resources mention common infrastructure, service quality, accessibility, hotels and market relations (Dwyer \& Kim, 2003; Mulec \& Wise, 2013; Zainuddin, Radzi, Zahari \& Ong, 2020). These sources are the resources of the destination's competitiveness, which easy to create a distinct advantage in competition.

Besides, the competitive advantage in this research is considered under two aspects: value to use and value for money. The value-to-use of a destination can be illustrated based on Crompton's classification of tourist interests in terms of meeting sociological needs. These benefits include motivating factors, such as escaping from the daily environment, exploring and evaluating oneself, relaxation, social awareness, social interaction, seeking novelty, and knowledge (Crompton, 1979). Value for money is considered a form of value based on the exchange between customer experience and services at the destination compared to the amount that customers are willing to pay (Gronroos, 2008). Grimsey \& Lewis (2004) believe that value for money is the optimal combination of quality (fit for purpose) and the full cost of a product or service to meet customer satisfaction. In this study, this value is considered based on the content discovered by Boo, Busser \& Baloglu (2009) as customers who feel this destination is worth the money for customers to experience and reasonable prices for customers to make a choice to come here instead of elsewhere.

In particular, the relationship between the factors of competitiveness in destinations and the value to use was confirmed by Pike et al. (2010) as a positive effect of the quality of destination attributes on guests. On the other hand, this relationship comes from the competitive resources of the destination that the business creates, which has created a distinct advantage in a competition that its purpose is to convert into customer benefits (Chi \& Qu, 2008; Zabkar, Brencic \& Dmitrovic, 2010). Value for money as a separate aspect that significantly affects customer perceptions of the value that businesses bring to customers (Boo, Busser \& Baloglu, 2009; Bianchi, Pike \& Ling, 2014). Chen \& Tsai (2007), the authors confirm that the aspect of resource resources has a strong and positive impact on the perceived value of customers. In another study by Chekalina, Fuchs \& Lexhagen (2018), the authors discovered that destination resources positively influence the perceived value of customers that it includes value to use and value for money.

\subsubsection{Relationships Among Value to Use, Value for Money and Loyalty of Visitors for Tourism Destination}

Visitor loyalty to the destination is an essential factor contributing to the development of a tourist destination. The intention to continue using the service and introduce destinations to people as well as the priority in this theory. The three most popular destination loyalty brand factors found in studies include destination referral readiness, destination return, and destination selection priority. (Konecnik \& Gartner, 2007; Boo, Busser, \& Baloglu, 2009). With the same perspective as Boo, Busser \& Baloglu (2009), Pike et al. (2010); Bianchi, Pike \& Ling (2014) defined the positive relationships between judgments and emotions of customers and loyalty. Besides, in a recent discovery by Chekalina, Fuchs \& Lexhagen (2016), it was discovered that among perceived values, including value to use and value for money, positively affect the loyalty of customers in using the service.

\section{Research Method}

\subsection{Research Design}

The research form of the article is exploratory research to adjust the factors and observation variables suitable for the case of the study that is the tourism industry in Vietnam.

Qualitative research is conducted to explore and perfect the elements of the scale and the research model. Discuss with experts to discover new factors or adapt them to the field of study. Discussion and in-depth interviews help eliminate ambiguous variables, the overlap between observable variables that mislead interviewees, and correct some words for clarification and accurate reflection and nature of the problem to be studied. 


\subsection{Recommended Scale}

To get the initial scale, the author conducts an overview of the theoretical foundations on competitive advantage and inherits empirical studies in the field of tourism to draw initial research findings for the topic. Specifically, the scale of resource resources, including inherited resources, created resources, and support resources inherited from two authors, Dwyer \& Kim (2003); Mulec \& Wise, (2013).

After the preliminary scale, a qualitative study was used through discussion in June 2020 and in-depth interviews in July 2020. Conduct discussions with Vietnam ten managers at tourism facilities in Vietnam include one director of Binh Thuan Department of Culture, Sports and Tourism; two deputy directors of Dong Nai Tourism Promotion Center and seven managers of travel agencies including Vietravel, Fiditour, Lua Viet, Saigontourist, Vietcharm Travel, DulichViet, and Peace Tour to understand the concepts and operating characteristics of industry enterprises in the study area. This study's results are the basis for the author to develop a draft scale used for in-depth interviews. After that, they were conducting in-depth interviews with two experts including a deputy director and one head of a department of in the industry who is working in the Tourism Department of Ho Chi Minh City to discover the factors affecting competitive advantage, adjusting the scale to suit the characteristics of the competitive advantage in the Vietnamese market in general and the field of tourism destination in particular. With the characteristics of Vietnam tourism, the author has revised the destination to a specific location in Vietnam. During group discussions and in-depth interviews, the scale of resources capacity is retained and inherited the original from the research of Dwyer \& Kim (2003); Mulec \& Wise (2013). Besides, the experts suggested that for the scale of the value of use, it should add more content about having many exciting experiences. Adding this scale is because nowadays, especially for young people, finding new and unique feelings different from the country they live in will help them have much pride inspired during travel. Besides, when visiting a particular tourist destination, especially foreign ones, tourists want to come to a specific destination, but they like to experience many places, many different landscapes, and features. Different characteristics, so the variety of experiences for the same country, is also one of the aspects that should be considered in terms of value used in the perception of tourists. Besides, according to the two in-depth interviews, the value for money here must be considered from different angles, not only related to reasonable prices and value for money. Each different tourist destination will target a different group of customers. Therefore, the reasonable price scale is not enough because depending on each object, they will define this logical word differently. The payment for a luxury tour with up to one hundred million for the upper class is considered reasonable, or spending about ten million for the middle class is considered reasonable... Therefore, value for money here should add a scale that matches each person's unique economic conditions. Therefore, after in-depth interviews with experts, the author decided to add a scale of "Vietnam destination suitable for my financial condition" to the content of value for money. From the results of the qualitative research, the official scale is calibrated and described as the table below:

Table 1. Scale source

\begin{tabular}{|c|c|c|}
\hline No. & Scale & Sources \\
\hline \multicolumn{3}{|c|}{ Inheritance Resources } \\
\hline & Vietnam climate is comfortable for tourism & \multirow{5}{*}{$\begin{array}{l}\text { Dwyer \& Kim (2003); Mulec } \\
\text { \& Wise, (2013) }\end{array}$} \\
\hline 02 & Vietnam has a clean and hygienic environment for tourism & \\
\hline 03 & Wonders, natural landscapes of Vietnam are attractive & \\
\hline 04 & Flora and fauna in Vietnam are plentiful & \\
\hline 05 & Vietnam has a wild nature & \\
\hline \multicolumn{3}{|c|}{ Created Resources } \\
\hline & Quality accommodation in Vietnam & \multirow{7}{*}{$\begin{array}{l}\text { Dwyer \& Kim (2003); Mulec } \\
\& \text { Wise, (2013) }\end{array}$} \\
\hline & Vietnam has many types of accommodation & \\
\hline & Vietnam accommodation has aesthetics and good location & \\
\hline & Vietnam has good airports & \\
\hline 05 & Vietnam has excellent travel guides and information & \\
\hline & Vietnam has good tourist signs & \\
\hline & Vietnam has diverse programs for travelers & \\
\hline
\end{tabular}




\begin{tabular}{|c|c|c|}
\hline \multicolumn{3}{|c|}{ Support Resources } \\
\hline 01 & Vietnam has adequate infrastructure & \multirow{5}{*}{$\begin{array}{l}\text { Dwyer \& Kim (2003); Mulec } \\
\text { \& Wise, (2013); Zainuddin, } \\
\text { Radzi, Zahari \& Ong (2020) }\end{array}$} \\
\hline 02 & Vietnam has good medical facilities for serving tourists & \\
\hline 03 & $\begin{array}{l}\text { Vietnam has good financial institutions and currency exchange } \\
\text { facilities }\end{array}$ & \\
\hline 04 & Vietnam has good telecommunication system & \\
\hline 05 & Vietnam has a good local transportation system & \\
\hline \multicolumn{3}{|c|}{ Value To Use } \\
\hline & Vietnam is an attractive destination & \multirow{3}{*}{$\begin{array}{l}\text { Chekalina, Fuchs \& Lexhagen } \\
\text { (2018); Boo, Busser, and } \\
\text { Baloglu (2009) }\end{array}$} \\
\hline & Vietnam brings many meaningful memories & \\
\hline 03 & Vietnam offers lots of fun and excitement & \\
\hline & Vietnam provides me with many diverse experiences & Additional expert opinions \\
\hline \multicolumn{3}{|c|}{ Value For Money } \\
\hline & Vietnam tourism has a reasonable price & \multirow{2}{*}{$\begin{array}{l}\text { Chekalina, Fuchs \& Lexhagen } \\
\text { (2018); Boo, Busser, and } \\
\text { Baloglu (2009) }\end{array}$} \\
\hline & $\begin{array}{l}\text { Compared to other destinations, coming to Vietnam is worth the } \\
\text { money }\end{array}$ & \\
\hline & Vietnam destination is suitable for my financial condition & Additional expert opinions \\
\hline \multicolumn{3}{|c|}{ Loyalty } \\
\hline & I will come back to Vietnam for other times & \multirow{2}{*}{$\begin{array}{l}\text { Konecnik \& Gartner (2007); } \\
\text { Boo, Busser \& Baloglu (2009) }\end{array}$} \\
\hline & Vietnam is my first choice & \\
\hline
\end{tabular}

\section{Findings}

The study was conducted to determine the relationship between competitiveness, competitive advantage, and loyalty of tourists to Vietnam tourism destination. Accordingly, the unique ability to create competitive advantages of Vietnam's tourism destinations is the capacity in resources including three aspects: inherited resources, created resources, and support resources. Competitive advantage is also reflected in the value to use and value for money of the tourist destination. These two values contribute to the visitor's loyalty to the tourist destination. In the research, authors have built scales measured following the characteristics of tourism in Vietnam. Accordingly, adjust the factors and observed variables to suit the case study in the tourism industry with the study area in Vietnam. From the research results, scholars in the field of tourism will have an additional source of reference for competitive advantage. Also, the study provides suggestions for managers in this field to have more bases to have appropriate plans for the sustainable development of tourism in Vietnam.

\section{Conclusion}

By qualitative research methods through in-depth discussions and interviews, the authors have adjusted the observed factors and variables inherited from Porter's theory of competitiveness (1990) to adapt to the context of the tourism industry in Vietnam. Accordingly, Accordingly, determining the structural sources capacity factors of the tourism destination including inheritance resources, created resources, and support resources and the relationship between source capacity, value to use, value for money, and loyalty of visitors to tourism destination in Vietnam. Within the scope of this topic, only at the qualitative stage to propose scales and research models but have not conducted quantitative research to verify the suitability and reliability in the field of tourism in Vietnam. In the next research direction, the authors can carry out quantitative research to complete the research results, thereby having enough reliability for the theoretical model to contribute more experimental cases to the theory of advantages competition, and there is more basis to propose implications for managers to plan strategies on competitive advantage in tourism.

\section{References}

Azzopardi, E., Margeta, J., Micalef, P., \& Mangion, J. (2001). Integrated water resources management plan for the north-west area of the Maltese island: CAMP project. Malta: Institute for Water Technology. 
Baron, S., \& K. Harris. (2010). Toward and Understanding of Consumer Perspective on Experiences. Journal of Services Marketing, 24(7), 518-31.

Bianchi, C., Pike, S., \& Ling, I. (2014). Investigating Attitudes towards Three South American Destinations in an Emerging Long Haul Market Using a Model of Consumer-Based Brand Equity (CBBE). Tourism Management, 42, 215-23.

Boo, S., Busser, J., \& Baloglu, S. (2009). A Model of Customer- Based Brand Equity and Its Application to Multiple Destinations. Tourism Management, 30(2), 219-31.

Caber, M., Albayrak, T., \& Matzler, K. (2012). Classification of the destina- tion attributes in the content of competitiveness (by revised importance-performance analysis). Journal of Vacation Marketing, 18(1), 43-56. https://doi.org/10.1177/1356766711428802

Claver, E., López, M. D., Molina, J. F., \& Tarí, J. J. (2007). Environmental management and firm performance: A $\begin{array}{llll}\text { case study. Journal of Environmental Management, } & \text { 84(4), 606-619. }\end{array}$ https://doi.org/10.1016/j.jenvman.2006.09.012

Cooper, C., Fletcher, J., Gilbert, D., \& Wanhill, S. (1998). Tourism: Principles and practice. London: Prentice Hall.

Crompton, J. L. (1979). Motivations for Pleasure Vacation. Annals of Tourism Research, 6(4), 408-24.

Chekalina, T., Fuchs, M., \& Lexhagen, M. (2016). Customer-Based Destination Brand Equity Modeling: The Role of Destination Resources, Value for Money, and Value in Use. Journal of Travel Research, 57(1), 31-51. https://doi.org/10.1177/0047287516680774

Chen, C. F., \& Myagmarsuren, O. (2010). Exploring Relationships between Mongolian Destination Brand Equity, Satisfaction and Destination Loyalty. Tourism Economics, 16(4), 981-94.

Chen, C. F., \& Tsai, D. (2007). How Destination Image and Evaluative Factors Affect Behavioral Intentions?. Tourism Management, 28(4), 1115-22.

Chi, C. G. Q., \& Qu, H. L. (2008). Examining the Structural Relationships of Destination Image, Tourist Satisfaction and Destination Loyalty: An Integrated Approach. Tourism Management, 29(4), 624-36.

Dwyer, L., \& Kim, C. (2003). Destination competitiveness: Determinants and indicators. Current Issues in Tourism, 6(5), 369-414. https://doi. org/10.1080/13683500308667962

Enright, M. J., \& Newton, J. (2004). Tourism destination competitiveness: a quantitative approach. Tourism Management, 25, 777-788.

Faulkner, B., Opperman, M., \& Fredline, E. (1999). Destination competitive- ness: An exploratory examination of South Australia's core attractions. Journal of Vacation Marketing, 5(2), 125-139. https://doi.org/10.1177/135676679900500202

Gearing, C. E., Swart, W. W., \& Var, T. (1974). Establishing a measure of touristic attractiveness. Journal of Travel Research, 12(4), 1-8.

Go, F., \& Govers, R. (2000). Integrated quality management for tourist des- tinations: A European perspective on $\begin{array}{lllll}\text { achieving } & \text { competitiveness. } & \text { Tourism } & \text { Management, } & 21(1),\end{array}$ https://doi.org/10.1016/S0261-5177(99)00098-9

Grimsey, D., \& Lewis, M. K. (2005). Are Public Private Partnerships value for money?. Accounting Forum, 29(4), 345-378. https://doi.org/10.1016/j.accfor.2005.01.001

Gronroos, C. (2006). Adopting a Service Logic for Marketing. Marketing Theory, 6(3), 317-33.

Konecnik, M., \& Gartner, W. C. (2007). Customer-based Brand Equity for a Destination. Annals of Tourism Research, 34(2), 400-421.

Kozak, M., \& Rimmington, M. (2000). Tourist satisfaction with Moallorca, Spain as anoff-season holiday destination. Journal of Travel Research, 260-269.

Melian-Gonzalez, A., \& Garcia-Falcon, J. M. (2003). Competitive potential of tourism destinations. Academy of Management Journal, 30(3), 720-740.

Mulec, I., \& Wise, N. (2013). Indicating the competitiveness of Serbia's Vojvodina Region as an emerging tourism destination. Tourism Management Perspectives, 8, 68-79. https://doi.org/10.1016/j.tmp.2013.07.001 
Pearce, D. (1997). Competitive destination analysis in Southeast Asia. Journal of Travel Research, 35(4), 16-24. https://doi.org/10.1177/004728759703500403

Pike, S., Bianchi, C., Kerr, G., \& Patti, C. (2010). Consumerbased Brand Equity for Australia as a Long-Haul Tourism Destination in an Emerging Market. International Marketing Review, 27(4), 434-49.

Porter, M. (2003). The Economic Performance of Regions. Regional Studies, 37(6/7), 549-578. https://doi.org/10.1080/0034340032000108688

Porter, M. E. (1990). The Competitive Advantage of Nations. Free Press: New York, NY, USA.

Porter, M. E., Sachs, J. D., \& Mc.Arthur, J. W. (2001). Executive Summary: Competitiveness and Stages of Economic Development. In The Global Competitiveness Report 2001-2002, World Economic Forum. Oxford: Oxford University Press, pp. 16-25.

Ritchie, J., \& Crouch, G. (2000). The competitive destination: A sustainabil- ity perspective. Tourism Management, $21,1-7$.

Ritchie, J., \& Crouch, G. (2003). The competitive destination: A sustainable tourism perspective. Oxon: CABI Publishing. https://doi.org/10.1079/9780851996646.0000

Turnbull, D. R., \& Uysal, M. (1995). An Exploratory Study of German Visitors to the Caribbean: Push and Pull Motivations. Journal of Travel and Tourism Marketing, 4(2), 85-92.

Vargo, S. L. (2009). Toward a Transcending Conceptualization of Relationship: A Service-Dominant Logic Perspective. Journal of Business and Industrial Marketing, 24(5/6), 373-79.

Vengesayi, S. (2013). Destination Competitiveness: The Impact of Destination Resources, Support Services and Human Factors, Journal of Tourism, 14(1), 79-108.

Zabkar, V., Brencic, M. M., \& Dmitrovic, T. (2010). Modelling Perceived Quality, Visitor Satisfaction and Behavioral Intentions at the Destination Level. Tourism Management, 31, 537-46.

Zainuddin, Z., Radzi, S. M., Zahari, M. S. M., \& Ong, M. H. A. (2020). Perceived destination competitiveness and response behavior: A test of mediation. Journal of Tourism, Hospitality \& Culinary Arts, 12(1), 279-288.

\section{Copyrights}

Copyright for this article is retained by the author(s), with first publication rights granted to the journal.

This is an open-access article distributed under the terms and conditions of the Creative Commons Attribution license (http://creativecommons.org/licenses/by/4.0/). 